\title{
Resistance of common bean (Phaseolus vulgaris) cultivars to Spodoptera frugiperda (Lepidoptera: Noctuidae)
}

\author{
Resistencia de cultivares de frijol (Phaseolus vulgaris) a Spodoptera frugiperda (Lepidoptera: Noctuidae) \\ LÍGIA ALVES DE PAIVA ${ }^{1}$, WANESSA DE CARVALHO RESENDE² ${ }^{2}$ CINTHIA LUZIA TEIXEIRA SILVA², \\ ANDRÉ CIRILO DE SOUSA ALMEIDA ${ }^{3}$, PAULO CESAR RIBEIRO DA CUNHA ${ }^{4}$ \\ and FLÁVIO GONÇALVES DE JESUS ${ }^{4}$
}

\begin{abstract}
Spodoptera frugiperda (Lepidoptera: Noctuidae) damages bean crops, resulting in decreased leaf area and destruction of reproductive structures. This study aimed to evaluate the types and levels of resistance of bean cultivars to $S$. frugiperda. The bean cultivars evaluated were: BRS Ametista, Pérola, BRS Notável, BRS Realce, Jalo Precoce, BRS Campeiro, BRS Agreste, BRS Cometa, BRS Executivo and BRS Pitanga, in the Laboratory of Agricultural Entomology of the Goiano Federal Institute, Urutaí Campus, Brazil. Tests to identify levels of antixenosis, in freechoice and no-choice tests, and antibiosis were performed in the laboratory $\left(25 \pm 2{ }^{\circ} \mathrm{C}, 70 \pm 10 \% \mathrm{R}\right.$. $\mathrm{H}$. and photophase of $14 \mathrm{~h}$ ). The cultivars BRS Pitanga, BRS Executivo, BRS Notável and BRS Campeiro presented antixenosis and BRS Realce antibiosis to $S$. frugiperda. However, it is not known whether the levels of resistance exhibited in the laboratory are sufficiently high to be of any economic value to agriculture. Therefore, the next step is to evaluate, under field conditions, the cultivars showing the most resistance in laboratory tests. If field evaluations indicate sufficient levels of resistance to be of practical value, these cultivars may be used as donor sources in the breeding program or may be used directly by farmers.
\end{abstract}

Key words: Fall armyworm, antibiosis, antixenosis, host plant resistance.

Resumen: Spodoptera frugiperda (Lepidoptera: Noctuidae) es una plaga que provoca daños en los cultivos de fríjol al reducir el área foliar y destruir las estructuras reproductivas. Este trabajo tuvo como objetivo evaluar los tipos y niveles de resistencia de cultivares de frijol a $S$. frugiperda. Los cultivares evaluados fueron: BRS Ametista, Pérola, BRS Notável, BRS Realce, Jalo Precoce, BRS Campeiro, BRS Agreste, BRS Cometa, BRS Executivo y BRS Pitanga, en el Laboratorio de Entomología Agrícola del Instituto Federal Goiano, Campus de Urataí, Brasil. Antixenosis, a libre y no libre escogencia y antibiosis se evaluaron en laboratorio $\left(25 \pm 2{ }^{\circ} \mathrm{C}, 70 \pm 10 \% \mathrm{HR}\right.$ y fotoperiodo $\left.14 \mathrm{~h}\right)$. Los cultivares BRS Pitanga, BRS Executivo, BRS Notável y BRS Campeiro presentaron antixenosis y BRS Realce antibiosis a $S$. frugiperda. Sin embargo, no se sabe si los niveles de resistencia, exhibidos en el laboratorio, son suficientemente altos que representen un valor económico de campo para los agricultores. Por lo tanto, el próximo paso es evaluar, en condiciones de campo, los cultivares que mostraron mayor resistencia en las pruebas de laboratorio. Si las evaluaciones de campo indican niveles de resistencia suficientes, para tener un valor práctico, estos cultivares pueden utilizarse como fuentes en el programa de mejoramiento o ser utilizados directamente por los agricultores.

Palabras clave: Cogollero del maíz, antibiosis, antixenosis, resistencia de plantas a insectos.

\section{Introduction}

The common bean (Phaseolus vulgaris L.) has a high economic and social importance in Brazil, because of its nutritional properties and the labor employed in its cultivation (Pedrosa et al. 2015). However, pest insects attacks cause losses in crop productivity (Jesus et al. 2010a, b; Janini et al. 2011). Among the insect pests attacking common bean, the fall armyworm - Spodoptera frugiperda (J. E. Smith, 1797) (Lepidoptera: Noctuidae) is of major importance because the feeding damage results in leaf area reduction and destruction of the reproductive structures.

Spraying of insecticides is the most common means of controlling S. frugiperda. However, this practice contributes to unbalanced agroecosystems (Bernardi et al. 2012) and the selection of insect resistant populations (Cruz et al. 2010). The use of alternative pest control methods, such as plant resistance to insects, is an important component in an integrated pest management (IPM) approach (Jesus et al. 2010a, b; Janini et al. 2011; Silva et al. 2016).

Plant resistance to insects (PRI) is considered an efficient method of pest control. PRI maintains the pest population below the level of economic damage, does not cause adverse effect on the environment, does not incur additional cost and may be compatible with other control methods (Lara 1991; Smith 2005; War et al. 2012; Seifi et al. 2013).

Plant resistance mechanisms are classified as antixenosis, antibiosis and tolerance. Antixenosis occurs when there is a deterrence of the plant for feeding, oviposition or shelter. Antibiosis is characterized by detrimental effects on insect biology and tolerance is the plant capacity to endure or recover from insect caused damage, through the production of new vegetative or reproductive structures (Gatehouse 2002; Cunningham 2012; War et al. 2012; Seifi et al. 2013).

\footnotetext{
${ }^{1}$ M. Sc. Universidade Estadual de Goiás, Campus Ipameri, Rodovia GO 330, Km 241, Setor Universitário - CEP 75780-000, Ipameri, Goiás, Brazil, ligia. agropaiva@outlook.com.2Agronomy, Instituto Federal Goiano, Campus Urutaí, Goiás, Brazil, wanessaresende_wr@hotmail.com, cinthiateixeirasilva@ hotmail.com. ${ }^{3}$ M. Sc. Instituto Federal Goiano, Campus Urutaí, Rodovia Prof. Geraldo Silva Nascimento, km 2,5 - CEP: 75790-000, Urutaí, Goiás, Brazil, andre_cirillo@ hotmail.com. ${ }^{4} \mathrm{Ph}$. D. Instituto Federal Goiano, Campus Urutaí, Rodovia Prof. Geraldo Silva Nascimento, km 2,5 - CEP: 75790-000, Urutaí, Goiás, Brazil,pcdacunha@hotmail.com,fgjagronomia@zipmail.com.br. Corresponding author: André Cirilo de Sousa Almeida. M. Sc. Instituto Federal Goiano, Campus Urutaí, Rodovia Prof. Geraldo Silva Nascimento, km 2,5 - CEP: 75790-000, Urutaí, Goiás, Brazil, andre_cirillo@ hotmail.com.
} 
Several studies to select bean genotypes resistant to stored grain pests have been conducted. However, few studies have examined insects that attack bean plants in the field. Considering the importance of bean crops for food security in Brazil, and the damage caused by defoliating caterpillars that injure reproductive structures, the selection of resistant genotypes is an important IPM strategy (Maldonado et al. 1996; Bottega et al. 2011; Boiça Júnior et al. 2015).

In previous studies the bean genotypes IAC Jabola, Arcelina 1, IAC Boreal, Flor de Mayo and IAC Formoso have been reported to present antixenosis to oviposition, and Arcelina 4, BRS Horizonte, Pérola, H96A102-1-1-152, IAC Boreal, IAC Harmonia and IAC Formoso presented antixenosis to feeding by Chrysodeixis includens (Walker, 1858) (Lepidoptera: Noctuidae) (Morando et al. 2015). Our study was conducted to identify resistance in common bean cultivars to $S$. frugiperda. In this preliminary study, leaves of the common bean were evaluated for antixenosis and antibiosis in the laboratory. Further field evaluations will be based on the results of this study.

\section{Materials and methods}

The experiments were conducted in a climate-controlled room $\left(25 \pm 1{ }^{\circ} \mathrm{C}, 70 \pm 10 \% \mathrm{RH}\right.$ and a 12 -h photophase $)$ at the Laboratory of Agricultural Entomology of the Goiano Federal Institute, Urutaí Campus, Brazil. The test varieties were obtained from the germplasm bank of the National Center of Research Rice and Beans - EMBRAPA Rice and Beans, Santo Antonio de Goiás, Goiás, Brazil. The following common bean cultivars were evaluated: BRS Ametista, Pérola, BRS Notável, BRS Realce, Jalo Precoce, BRS Campeiro, BRS Agreste, BRS Cometa, BRS Executivo and BRS Pitanga. These varieties were selected because common bean producers in Brazil currently cultivate them.

To rear $S$. frugiperda, adults collected in the field were placed in cages of polyvinyl chloride (PVC) tubes $(10 \mathrm{~cm}$ in diameter and $21.5 \mathrm{~cm}$ high) covered internally with white paper sheets, which served as oviposition sites (Campos et al. 2012; Jesus et al. 2014). The newly hatched larvae were placed on artificial diet for rearing (Greene et al. 1976). The common bean cultivars were sown in $5 \mathrm{~L}$ plastic pots containing soil, manure and sand $(2: 1: 1)$ mixture as substrate. Following germination, plants were thinned to one plant per pot, and grown in a greenhouse until 30 days after emergence (DAE).

Antixenosis. Attractiveness of the cultivars in a free-choice test was determined by releasing 20 third instar S. frugiperda larvae per cultivar. Bean leaves were collected from plants at $30 \mathrm{DAE}$, washed with distilled water, cut into $2.5 \mathrm{~cm}^{2}$ leaf disks, and distributed in a circular manner, over moistened filter paper, in a Petri dish (14 cm diameter). A randomized block design, with ten replicates, was used for this bioassay.

The attractiveness in a no-choice test was performed by offering the same cultivars individually. The leaves were collected and prepared as described for the previous test. One leaf disk was placed on moistened filter paper Petri dish $(6$ $\mathrm{cm}$ diameter) and one third instar larva was placed in each petri dish. A completely randomized experimental design was used with 15 replicates.

For both tests the attractiveness of $S$. frugiperda was evaluated at $3,5,10,15$ and 30 minutes, as well as at 1, 3,
6 and 12 hours following caterpillar release by counting the number of insects attracted to the leaf disk of each cultivar at each time period. The tests were completed at 12 hours following caterpillar release.

Antibiosis. Newly hatched $S$. frugiperda larvae were placed in Petri dishes (6 $\mathrm{cm}$ in diameter) containing moistened filter paper and sealed with polyethylene film. The larvae were fed with a trifoliate leaf collected from the plant apex which were replaced daily or after consumption. Larvae were kept in the Petri dishes until the pupal stage when the leaf supply was terminated. Adults (moths) were not fed.

The following biological parameters were recorded: 13-day-old larva weight ( $\mathrm{mg}$ ), larval and pupal stage duration (days), pupal weight (mg), adult longevity (days), larval and pupal viability (percent that completed the larval and pupal stage respectively), and total life cycle (days). A completely randomized experimental design was used with 25 replicates.

Statistical analysis. The data were subjected to an analysis of variance (ANOVA) and the means were compared using the Tukey's test at $5 \%$ probability in Sisvar 5.3 (Ferreira 2011). A principal component analysis and a cluster analysis test were performed, and dissimilarity was measured using Euclidean distances to identify groups of common bean cultivars with different degrees of resistance (StatSoft 2004).

\section{Results and discussion}

The free-choice attractiveness test revealed differences among the common bean cultivars tested to S. frugiperda at 5 and 30 minutes, as well as at 3,6 and 12 hours (Table 1). At 5 min larvae of $S$. frugiperda were not attracted by cultivars BRS Ametista, Pérola, BRS Notável, BRS Agreste, BRS Cometa and BRS Pitanga. BRS Realce and Jalo Precoce were the most attractive at $5 \mathrm{~min}$. At $30 \mathrm{~min}$ Pérola, BRS Executivo and BRS Pitanga were not infested and Jalo Precoce and BRS Campeiro were the most attractive cultivars to $S$. frugiperda. At $3 \mathrm{~h}$ all genotypes were not infested by $S$. frugiperda except BRS Agreste and BRS Campeiro. At $3 \mathrm{~h}$ the cultivar BRS Campeiro showed the most attractiveness to $S$. frugiperda. Overall, the cultivars BRS Pitanga and BRS Executivo were the least attractive to $S$. frugiperda. BRS Campeiro was the most attractive.

The no-choice attractiveness test revealed significant differences between the cultivars at 5,15 and $30 \mathrm{~min}$. At 5 min BRS Notável, BRS Campeiro, BRS Executivo were not infested and BRS Agreste was the most attractive to $S$. frugiperda. At 15 min Pérola, BRS Notável, BRS Realce, Jalo Precoce, BRS Campeiro and BRS Pitanga were not infested and BRS Agreste was the most attractive and $30 \mathrm{~min}$ Pérola had low larval numbers and BRS Agreste again was the most attractive cultivar to $S$. frugiperda. Generally, BRS Notável, BRS Campeiro, BRS Executivo and BRS Pitanga cultivars were the least attractive to $S$. frugiperda and BRS Agreste was the most attractive.

BRS Pitanga, BRS Executivo and BRS Campeiro cultivars showed antixenosis to $S$. frugiperda (Tables 1 and 2 ). This indicates the presence of chemical compounds and/or morphological leaf characteristics in these cultivars that are repellent to S. frugiperda (Cunningham 2012). Few studies have characterized the types of resistance present in common bean cultivars upon defoliating insects. Morando et al. 
Table 1. Number $( \pm \mathrm{SEM})$ of third instar Spodoptera frugiperda larvae on leaves of different common beans cultivars at a given time in a free-choice test.

\begin{tabular}{|c|c|c|c|c|}
\hline \multirow{2}{*}{ Cultivars } & \multicolumn{4}{|c|}{ Time in minutes } \\
\hline & 5 & 10 & 15 & 30 \\
\hline BRS Ametista & $0.00 \pm 0.00^{b}$ & $0.00 \pm 0.00$ & $0.20 \pm 0.13$ & $0.10 \pm 0.10^{\mathrm{ab}}$ \\
\hline Pérola & $0.00 \pm 0.00^{\mathrm{b}}$ & $0.10 \pm 0.10$ & $0.10 \pm 0.10$ & $0.00 \pm 0.00^{b}$ \\
\hline BRS Notável & $0.00 \pm 0.00^{b}$ & $0.20 \pm 0.13$ & $0.10 \pm 0.10$ & $0.20 \pm 0.13^{\mathrm{ab}}$ \\
\hline BRS Realce & $0.50 \pm 0.22^{\mathrm{a}}$ & $0.10 \pm 0.10$ & $0.30 \pm 0.21$ & $0.30 \pm 0.15 \mathrm{ab}$ \\
\hline Jalo Precoce & $0.50 \pm 0.22^{\mathrm{a}}$ & $0.20 \pm 0.13$ & $0.60 \pm 0.22$ & $0.70 \pm 0.21^{\mathrm{a}}$ \\
\hline BRS Campeiro & $0.30 \pm 0.15 \mathrm{ab}$ & $0.10 \pm 0.10$ & $0.30 \pm 0.21$ & $0.70 \pm 0.26^{\mathrm{a}}$ \\
\hline BRS Agreste & $0.00 \pm 0.00^{b}$ & $0.20 \pm 0.13$ & $0.10 \pm 0.00$ & $0.10 \pm 0.10^{\mathrm{ab}}$ \\
\hline BRS Cometa & $0.00 \pm 0.00^{b}$ & $0.10 \pm 0.10$ & $0.00 \pm 0.10$ & $0.10 \pm 0.10 \mathrm{ab}$ \\
\hline BRS Executivo & $0.10 \pm 0.10^{a b}$ & $0.10 \pm 0.10$ & $0.10 \pm 0.10$ & $0.00 \pm 0.00^{\mathrm{b}}$ \\
\hline BRS Pitanga & $0.00 \pm 0.00^{\mathrm{b}}$ & $0.00 \pm 0.00$ & $0.10 \pm 0.10$ & $0.00 \pm 0.00^{\mathrm{b}}$ \\
\hline F (trat.) & $3.14 *$ & $0.57^{\mathrm{NS}}$ & $1.39^{\mathrm{NS}}$ & $4.03 *$ \\
\hline C.V (\%) & 23.34 & 20.77 & 27.70 & 25.12 \\
\hline \multirow{2}{*}{ Cultivars } & \multicolumn{4}{|c|}{ Time in hours } \\
\hline & 1 & 3 & 6 & 12 \\
\hline BRS Ametista & $0.10 \pm 0.10$ & $0.00 \pm 0.00^{b}$ & $0.20 \pm 0.13 \mathrm{ab}$ & $0.20 \pm 0.26 \mathrm{ab}$ \\
\hline Pérola & $0.00 \pm 0.00$ & $0.00 \pm 0.00^{\mathrm{b}}$ & $0.30 \pm 0.15^{a b}$ & $0.30 \pm 0.15$ ab \\
\hline BRS Notável & $0.00 \pm 0.00$ & $0.00 \pm 0.00^{\mathrm{b}}$ & $0.70 \pm 0.21^{\mathrm{ab}}$ & $0.70 \pm 0.29 \mathrm{ab}$ \\
\hline BRS Realce & $0.20 \pm 0.13$ & $0.00 \pm 0.00^{\mathrm{b}}$ & $0.10 \pm 0.10^{a b}$ & $0.10 \pm 0.10^{\mathrm{ab}}$ \\
\hline Jalo Precoce & $0.30 \pm 0.15$ & $0.00 \pm 0.00^{\mathrm{b}}$ & $0.20 \pm 0.13^{\mathrm{ab}}$ & $0.20 \pm 0.00^{\mathrm{ab}}$ \\
\hline BRS Campeiro & $0.80 \pm 0.51$ & $0.80 \pm 0.13^{\mathrm{a}}$ & $0.80 \pm 0.33^{a}$ & $0.80 \pm 0.27^{\mathrm{a}}$ \\
\hline BRS Agreste & $0.20 \pm 0.13$ & $0.20 \pm 0.13^{a b}$ & $0.40 \pm 0.22^{a b}$ & $0.40 \pm 0.22 \mathrm{ab}$ \\
\hline BRS Cometa & $0.00 \pm 0.00$ & $0.00 \pm 0.00^{\mathrm{b}}$ & $0.30 \pm 0.15^{\mathrm{ab}}$ & $0.30 \pm 0.15^{\mathrm{ab}}$ \\
\hline BRS Executivo & $0.00 \pm 0.00$ & $0.00 \pm 0.00^{\mathrm{b}}$ & $0.10 \pm 0.10^{\mathrm{ab}}$ & $0.10 \pm 0.10^{\mathrm{ab}}$ \\
\hline BRS Pitanga & $0.10 \pm 0.10$ & $0.00 \pm 0.00^{\mathrm{b}}$ & $0.00 \pm 0.00^{\mathrm{b}}$ & $0.00 \pm 0.00^{\mathrm{b}}$ \\
\hline F (trat.) & $1.77^{\mathrm{NS}}$ & $16.31 *$ & $2.30 *$ & $3.38 *$ \\
\hline C.V. $(\%)$ & 29.06 & 13.56 & 29.91 & 29.51 \\
\hline
\end{tabular}

${ }^{1}$ Means followed by the same letter are not different by Tukey's test at the $5 \%$ probability level. Data were transformed to $\left.(\mathrm{x}+0.5) 1 / 2\right)$ for analysis purposes. " Significant at $5 \%$ probability. ${ }^{\text {NS }}$ Non-significant.

(2015) reported antixenosis to C. includens in H96A102-1-11-52, Flor de Mayo and Arcelina 4 genotypes. Boiça Junior et al. (2015) observed antixenosis in IAC Una, IAC Uirapuru, IAC Diplomata and IAC Onix cultivars and tolerance in IAC Onix and IAC Una upon Diabrotica speciosa (Germar, 1924) (Coleoptera: Chrysomelidae).

The hierarchical cluster analysis performed for both attractiveness and antixenosis resistance against the third-instar larvae of $S$. frugiperda that were evaluated at different time periods in free-choice and no-choice tests revealed significant differences between the tested cultivars, separating them into groups according to their degree of similarity (Fig. 1). BRS Pitanga, Perola, BRS Ametista and BRS Executivo at Euclidean distance 3.3, 3.5 and 4.7, respectively, were grouped indicating similarity among these cultivars (Fig. 1). The second group was formed by BRS Cometa and BRS Notável at Euclidean distance 4.7, and the third group included Jalo Precoce and BRS Realce at Euclidean distance 4.9. Finally, all the cultivars were grouped at 7.4 (Fig. 1).

Considering a Euclidean distance of 5.0 as the criterion for group division, the tested cultivars were separated according

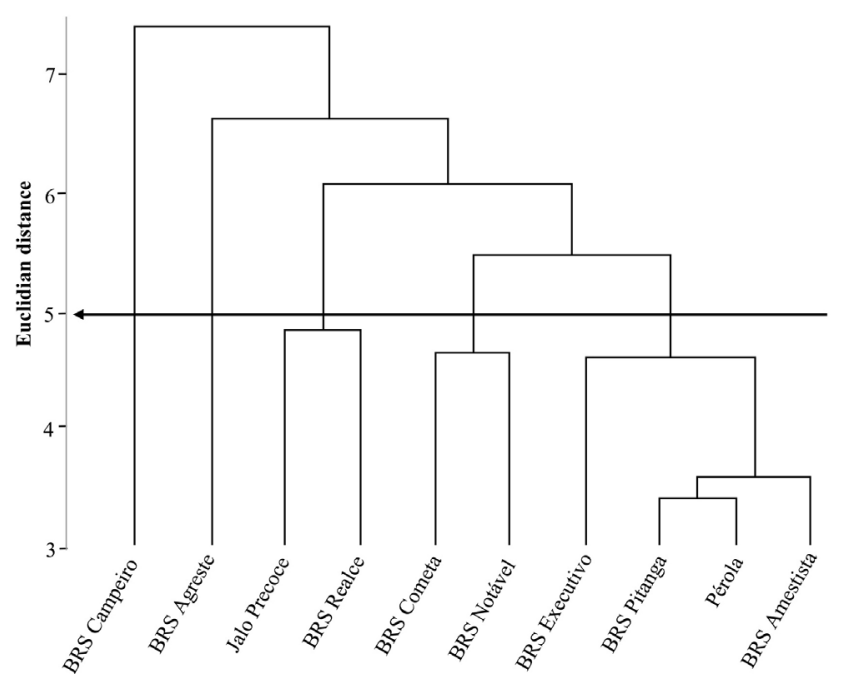

Figure 1. Dendrogram based on attractiveness of third instar Spodoptera frugiperda in free and non-choice tests by common bean. The hierarchical cluster analysis was carried out using the Ward's method with the Euclidean distance as dissimilarity measure. The arrow indicates the Euclidean distance used for the separation of groups (phenon line). 
Table 2. Number of third instar Spodoptera frugiperda larvae ( \pm SEM) on leaves of different common beans cultivars in a no-choice test.

\begin{tabular}{|c|c|c|c|c|}
\hline \multirow{2}{*}{ Cultivars } & \multicolumn{4}{|c|}{ Time in minutes ${ }^{1}$} \\
\hline & 5 & 10 & 15 & 30 \\
\hline BRS Ametista & $0.26 \pm 0.14^{\mathrm{ab}}$ & $0.20 \pm 0.13$ & $0.26 \pm 0.14^{\mathrm{ab}}$ & $0.20 \pm 0.13^{\mathrm{ab}}$ \\
\hline Pérola & $0.20 \pm 0.13 \mathrm{ab}$ & $0.13 \pm 0.11$ & $0.06 \pm 0.08^{b}$ & $0.00 \pm 0.00^{\mathrm{b}}$ \\
\hline BRS Notável & $0.06 \pm 0.08^{b}$ & $0.20 \pm 0.13$ & $0.13 \pm 0.11^{b}$ & $0.20 \pm 0.13 \mathrm{ab}$ \\
\hline BRS Realce & $0.20 \pm 0.13^{a b}$ & $0.13 \pm 0.11$ & $0.13 \pm 0.11^{b}$ & $0.13 \pm 0.11^{\mathrm{ab}}$ \\
\hline Jalo Precoce & $0.33 \pm 0.15 a b$ & $0.33 \pm 0.15$ & $0.13 \pm 0.11^{b}$ & $0.20 \pm 0.13 \mathrm{ab}$ \\
\hline BRS Campeiro & $0.06 \pm 0.08^{b}$ & $0.20 \pm 0.13$ & $0.06 \pm 0.08^{b}$ & $0.33 \pm 0.15$ ab \\
\hline BRS Agreste & $0.60 \pm 0.16^{\mathrm{a}}$ & $0.53 \pm 0.16$ & $0.60 \pm 0.16^{\mathrm{a}}$ & $0.53 \pm 0.16^{\mathrm{a}}$ \\
\hline BRS Cometa & $0.33 \pm 0.15^{\mathrm{ab}}$ & $0.20 \pm 0.13$ & $0.46 \pm 0.16^{\mathrm{ab}}$ & $0.33 \pm 0.15^{a b}$ \\
\hline BRS Executivo & $0.06 \pm 0.08^{b}$ & $0.13 \pm 0.11$ & $0.33 \pm 0.15^{a b}$ & $0.46 \pm 0.16^{\mathrm{ab}}$ \\
\hline BRS Pitanga & $0.06 \pm 0.08^{b}$ & $0.06 \pm 0.08$ & $0.06 \pm 0.08^{b}$ & $0.13 \pm 0.11 \mathrm{ab}$ \\
\hline F (trat.) & $2.86 *$ & $1.61 \mathrm{NS}$ & $3.38 *$ & $2.24 *$ \\
\hline C.V. $(\%)$ & 24.84 & 25.55 & 24.66 & 25.99 \\
\hline \multirow{2}{*}{ Cultivars } & \multicolumn{4}{|c|}{ Time in hours } \\
\hline & 1 & 3 & 6 & 12 \\
\hline BRS Ametista & $0.13 \pm 0.11$ & $0.46 \pm 0.16$ & $0.60 \pm 0.16$ & $0.73 \pm 0.14$ \\
\hline Pérola & $0.06 \pm 0.08$ & $0.26 \pm 0.14$ & $0.66 \pm 0.15$ & $0.60 \pm 0.16$ \\
\hline BRS Notável & $0.33 \pm 0.15$ & $0.26 \pm 0.14$ & $0.40 \pm 0.16$ & $0.86 \pm 0.11$ \\
\hline BRS Realce & $0.26 \pm 0.14$ & $0.13 \pm 0.11$ & $0.40 \pm 0.16$ & $0.46 \pm 0.16$ \\
\hline Jalo Precoce & $0.26 \pm 0.14$ & $0.20 \pm 0.13$ & $0.60 \pm 0.16$ & $0.80 \pm 0.13$ \\
\hline BRS Campeiro & $0.26 \pm 0.14$ & $0.26 \pm 0.14$ & $0.46 \pm 0.16$ & $0.86 \pm 0.11$ \\
\hline BRS Agreste & $0.33 \pm 0.15$ & $0.40 \pm 0.16$ & $0.60 \pm 0.16$ & $0.73 \pm 0.14$ \\
\hline BRS Cometa & $0.40 \pm 0.16$ & $0.26 \pm 0.14$ & $0.46 \pm 0.16$ & $0.60 \pm 0.16$ \\
\hline BRS Executivo & $0.13 \pm 0.11$ & $0.53 \pm 0.16$ & $0.86 \pm 0.11$ & $0.86 \pm 0.11$ \\
\hline BRS Pitanga & $0.00 \pm 0.00$ & $0.26 \pm 0.14$ & $0.66 \pm 0.15$ & $0.80 \pm 0.13$ \\
\hline F (trat.) & $1.50 \mathrm{Ns}$ & $1.05 \mathrm{NS}$ & $1.29 \mathrm{NS}$ & $1.47^{\mathrm{NS}}$ \\
\hline C.V. (\%) & 25.81 & 27.61 & 25.36 & 20.84 \\
\hline
\end{tabular}

${ }^{1}$ Means followed by the same letter are not different by Tukey's test at the $5 \%$ probability level. Data were transformed to $((\mathrm{x}+0.5) 1 / 2)$ for analysis purposes. " Significant at $5 \%$ probability. ${ }^{\text {NS }}$ Non-significant.

Table 3. Larval and pupal period (days) and larval and pupal weight (mg) of Spodoptera frugiperda (Lepidoptera: Noctuidae) fed on common bean cultivars.

\begin{tabular}{lcccc}
\hline \multicolumn{1}{c}{ Cultivars } & Larval period & Larval weight & Pupal period & Pupal weight \\
\hline BRS Ametista & $23.6 \pm 2.84^{\mathrm{ab}}$ & $0.156 \pm 0.03$ & $9.1 \pm 0.39^{\mathrm{ab}}$ & $156.0 \pm 0.01$ \\
Pérola & $19.1 \pm 0.62^{\mathrm{b}}$ & $0.172 \pm 0.04$ & $9.3 \pm 0.48^{\mathrm{ab}}$ & $153.0 \pm 0.01$ \\
BRS Notável & $18.7 \pm 0.47^{\mathrm{b}}$ & $0.276 \pm 0.04$ & $10.3 \pm 0.29^{\mathrm{ab}}$ & $163.0 \pm 0.01$ \\
BRS Realce & $27.2 \pm 1.24^{\mathrm{a}}$ & $0.104 \pm 0.02$ & $14.5 \pm 6.26^{\mathrm{a}}$ & $161.0 \pm 0.02$ \\
Jalo Precoce & $19.2 \pm 0.63^{\mathrm{b}}$ & $0.217 \pm 0.03$ & $7.7 \pm 0.28^{\mathrm{b}}$ & $131.0 \pm 0.01$ \\
BRS Campeiro & $18.3 \pm 0.76^{\mathrm{b}}$ & $0.222 \pm 0.04$ & $10.0 \pm 0.17^{\mathrm{ab}}$ & $164.0 \pm 0.01$ \\
BRS Agreste & $20.0 \pm 0.79^{\mathrm{b}}$ & $0.777 \pm 0.70$ & $9.5 \pm 0.34^{\mathrm{ab}}$ & $148.0 \pm 0.01$ \\
BRS Cometa & $19.5 \pm 0.99^{\mathrm{b}}$ & $0.179 \pm 0.02$ & $10.6 \pm 0.48^{\mathrm{ab}}$ & $151.0 \pm 0.00$ \\
BRS Executivo & $22.2 \pm 0.80^{\mathrm{b}}$ & $0.333 \pm 0.02$ & $10.7 \pm 0.28^{\mathrm{ab}}$ & $153.0 \pm 0.02$ \\
BRS Pitanga & $21.1 \pm 0.86^{\mathrm{b}}$ & $0.180 \pm 0.03$ & $10.2 \pm 0.81^{\mathrm{ab}}$ & $143.0 \pm 0.00$ \\
\hline F (trat.) & $4.87^{*}$ & $1.04^{\mathrm{NS}}$ & $4.41^{*}$ & $0.76^{\mathrm{NS}}$ \\
C.V. (\%) & $18.00^{\mathrm{ab}}$ & 28.86 & 36.93 & 22.04 \\
\hline
\end{tabular}

${ }^{1}$ Means followed by the same letter are not different by Tukey's test at the $5 \%$ probability level. Data were transformed to $\left.(\mathrm{x}+0.5) 1 / 2\right)$ for analysis purposes. " Significant at $5 \%$ probability. ${ }^{\text {NS }}$ Non-significant. 
Table 4. Larval and pupal viability (\%) ( \pm SEM) and adult longevity (days) of Spodoptera frugiperda (Lepidoptera: Noctuidae) fed on common bean cultivars.

\begin{tabular}{lccc}
\hline \multicolumn{1}{c}{ Cultivars } & Larval viability & Pupal viability & Adult longevity \\
\hline BRS Ametista & $36.00 \pm 5.00$ & $32.00 \pm 6.00$ & $3,80 \pm 0,29^{\mathrm{ab}}$ \\
Pérola & $36.00 \pm 5.00$ & $32.00 \pm 6.00$ & $3.10 \pm 0.15^{\mathrm{b}}$ \\
BRS Notável & $60.00 \pm 10.00$ & $56.00 \pm 8.00$ & $5.20 \pm 0.25^{\mathrm{a}}$ \\
BRS Realce & $48.00 \pm 8.00$ & $40.00 \pm 8.00$ & $4.20 \pm 0.25^{\mathrm{ab}}$ \\
Jalo Precoce & $36.00 \pm 5.00$ & $32.00 \pm 6.00$ & $3.50 \pm 0.38^{\mathrm{ab}}$ \\
BRS Campeiro & $44.00 \pm 7.00$ & $36.00 \pm 5.00$ & $4.20 \pm 0.24^{\mathrm{ab}}$ \\
BRS Agreste & $36.00 \pm 5.00$ & $32.00 \pm 6.00$ & $4.00 \pm 0.29^{\mathrm{ab}}$ \\
BRS Cometa & $48.00 \pm 8.00$ & $44.00 \pm 8.00$ & $4.50 \pm 0.23^{\mathrm{ab}}$ \\
BRS Executivo & $40.00 \pm 6.00$ & $36.00 \pm 5.00$ & $4.10 \pm 0.26^{\mathrm{ab}}$ \\
BRS Pitanga & $48.00 \pm 8.00$ & $44.00 \pm 8.00$ & $4.20 \pm 0.25^{\mathrm{ab}}$ \\
\hline F (trat.) & $1.12^{\mathrm{NS}}$ & $1.44^{\mathrm{NS}}$ & $4.82^{*}$ \\
C.V. (\%) & 32.33 & 30.32 & 29.32 \\
\hline
\end{tabular}

${ }^{1}$ Means followed by the same letter are not different by Tukey's test at the $5 \%$ probability level. Data were transformed to $(\mathrm{x}+0.5) 1 / 2)$ for analysis purposes. " Significant at $5 \%$ probability. ${ }^{\mathrm{NS}}$ Non-significant.

to the level of antixenosis resistance as follows: moderately resistant - BRS Campeiro and BRS Agreste; susceptible Jalo Precoce, BRS Realce, BRS Cometa and BRS Notável; and highly susceptible - BRS Executivo, BRS Pitanga, Pérola and BRS Ametista.

Comparing the results of the hierarchical cluster analysis with those of the free choice and no-choice attractiveness tests, BRS Campeiro was found to be one of the most attractive cultivar to $S$. frugiperda in free-choice test, despite its inclusion in the moderately resistant group (Table 1 and Fig. 1).

The common bean cultivars presented a significant effect on the biological parameters of $S$. frugiperda (Table 3). The larvae fed on cultivar BRS Realce presented a longer larval stage compared to the remaining cultivars, except for BRS Ametista. The larval phase prolongation in $S$. frugiperda caused by BRS Realce is characteristic of antibiosis (Smith 2005; Seifi et al. 2013). This data is in agreement with those of Jesus et al. (2014) that found antibiosis on cotton cultivar Nuopal to $S$. frugiperda that completed the larval stage in 23.3 days. Paiva et al. (2016) observed that $S$. frugiperda completed the same stage in BX 1293 YG antibiosis resistant corn in 31.85 days. Larvae of $S$. frugiperda fed on artificial diet had their larval stage completed in 16 days (Silva et al. 2016).

The pupae originating from larvae fed on BRS Realce also presented an extended pupal stage that was 6.8 days longer than those from Jalo Precoce. The adults presented a higher longevity after feeding on BRS Notável compared to Pérola (Table 4). The same authors mentioned previously found extension in the life cycle of $S$. frugiperda when fed on resistant plants. It is important to use as IPM tactic because over time there is a reduction in the population density of the pest (Gatehouse 2002).

The observed extension of the larval and pupal stages on S. frugiperda fed on BRS Realce indicates a detrimental effect

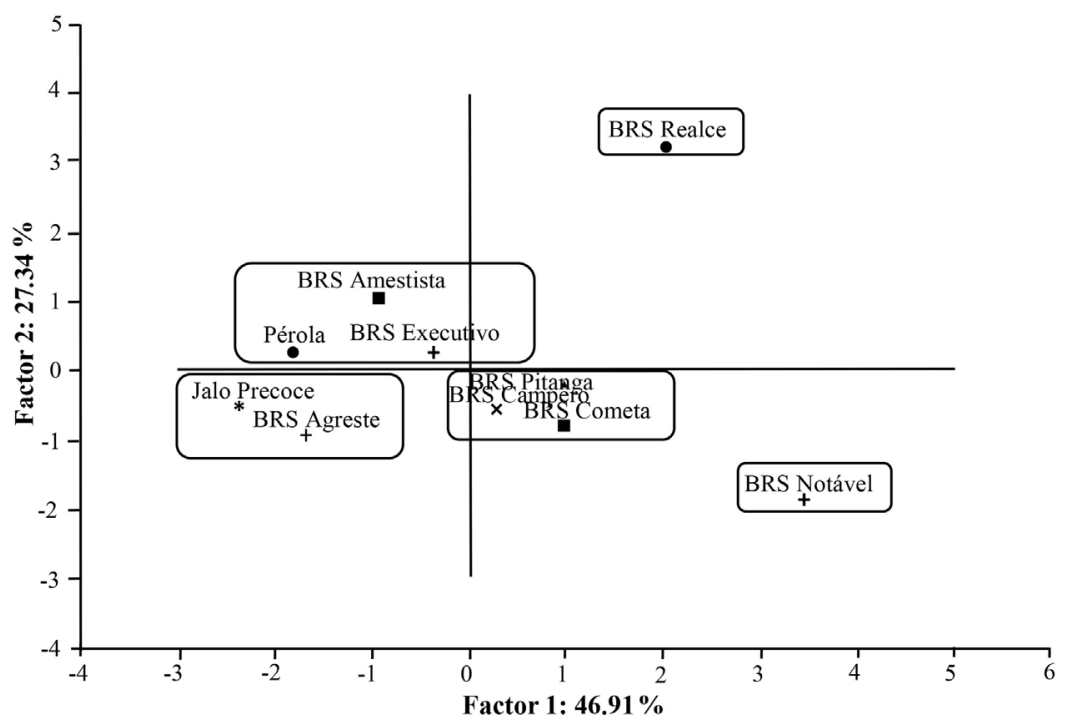

Figure 2. Distribution of the common bean cultivars according to principal component analysis based on biological parameters of Spodoptera frugiperda. 
of the plant on their biology. S. frugiperda needed more time to complete the larval and pupal stages than those feeding on a susceptible cultivar. Delays on $S$. frugiperda development are usually associated with antibiosis. Antibiosis is characterized by an extension on the larval stage when the insect feeds on a resistant host plant. This results in negative effects on initial insect developmental stages, such as high mortality, deformities and decreased body weight (Lara 1991; War et al. 2012; Seifi et al. 2013).

The principal component analysis separated the bean cultivars into four levels of antibiosis resistance: highly resistant - BRS Notável; moderately resistant - BRS Pitanga, BRS Campeiro, BRS Cometa and BRS Realce; susceptible - BRS Ametista, BRS Executivo and Pérola; and highly susceptible - Jalo Precoce and BRS Agreste (Fig. 2).

\section{Conclusions}

The cultivars BRS Pitanga, BRS Executivo, BRS Notável and BRS Campeiro presented antixenosis and BRS Realce antibiosis to $S$. frugiperda under laboratory conditions. However, it is not known whether the levels of resistance, exhibited in the laboratory, are sufficiently high, to be of any economic value in farmers' fields. Therefore, the next step is to evaluate, under field conditions, the cultivars showing the most resistance in the laboratory tests. If field evaluations indicate sufficient levels of resistance, to be of practical value, these cultivars may be used as donor sources in the breeding program or used directly by farmers.

\section{Acknowledgements}

This study was partially supported by National Council of Research and Technology of Brazil (CNPq) grant 311280/2015-3 to F. G. Jesus. We also thank the Instituto Federal Goiano - Campus Urutaí for support. Dr. E. A. "Short" Heinrichs from Department of Entomology to University of Nebraska - Lincoln for reviewing the manuscript and the anonymous reviewers for comments and corrections of this manuscript.

\section{Literature cited}

BERNARDI, O.; MALVESTITI, G. S.; DOURADO, P. M.; OLIVEIRA, W. S.; MARTINELLI, S.; BERGER, G. U.; HEAD, G. P.; OMOTO, C. 2012. Assessment of the high-dose concept and level of control provided by MON $87701 \times$ MON 89788 soybean against Anticarsia gemmatalis and Pseudoplusia includens (Lepidoptera: Noctuidae) in Brazil. Pest Management Science 68 (7): 1083-1091. doi:10.1002/ps.3271.

BOIÇA JUNIOR, A. L.; COSTA, E. N.; SOUZA, B. H. S.; RIBEIRO, Z. A.; CARBONELL, A. M. S. 2015. Antixenosis and tolerance to Diabrotica speciosa (Coleoptera: Chrysomelidae) in common bean cultivars. Florida Entomologist 98 (2): 464472. doi:10.1653/024.098.0212.

BOTTEGA, D. B.; RODRIGUES, C. A.; JESUS, F. G.; SILVA, A. G.; PEIXOTO, N. 2011. Resistência de genótipos de feijãovagem ao ataque de bruquíneos, em condições de laboratório. Revista Caatinga 25 (1): 92-97.

CAMPOS, Z. R.; BOIÇA-JÚNIOR, A. L.; VALÉRIO FILHO, W. V.; CAMPOS, O. R.; CAMPOS, A. R. 2012. The feeding preferences of Spodoptera frugiperda (J. E. Smith) (Lepidoptera: Noctuidae) on cotton plant varieties. Acta Scientiarum Agronomy 34 (1): 125-130.
CRUZ, I.; FIGUEIREDO, M. L. C.; SILVA, R. B.; FOSTER, J. E. 2010. Efficiency of chemical pesticides to control Spodoptera frugiperda and validation of pheromone trap as a past management tool in maize crops. Revista Brasileira de Milho e Sorgo 9 (2): 107-122.

CUNNINGHAM, J. P. 2012. Can mechanism help explain insect host choice? Journal of Evolutionary Biology 25 (2): 244-251. doi:10.1111/j.1420-9101.2011.02435.x.

FERREIRA, D. F. 2011. Sisvar: a computer statistical analysis system. Ciência e Agrotecnologia 35 (6): 1039-1042. doi:10.1590/S1413-70542011000600001.

GATEHOUSE, J. A. 2002. Plant resistance towards insect herbivores: a dynamic interaction. New Phytologist 156 (2): 145-169.

GREENE, G. L.; LEPPLA, N. C.; DICKERSON, W. A. 1976. Velvetbean caterpillar: a rearing procedure and artificial medium. Journal Economic Entomology 69 (4): 487-488.

JANINI, J. C.; BOIÇA JÚNIOR, A. L.; JESUS, F. G.; SILVA, A. G.; CARBONELL, S. A.; CHIORATO, A. F. 2011. Efeito de genótipos de feijoeiro, inseticida e produtos naturais no controle Bemisia tabaci (Gennadius) biotipo B (Hemiptera: Aleyrodidae) e Caliothrips phaseoli (Hood) (Thysanoptera: Thripidae). Acta Scientiarum Agronomy 33 (3): 445-450. doi:10.4025/ actasciagron.v33i3.7577.

JESUS, F. G.; BOIÇA JUNIOR, A. L.; CARBONELL, S. A. M.; STEIN, C. P.; PITTA, R. M.; CHIORATO, A. F. 2010a. Infestação de Bemisia tabaci biótipo B e Caliothrips phaseoli em genótipos de feijoeiro. Bragantia 69 (3): 637-648. doi:10.1590/ S0006-87052010000300016.

JESUS, F. G.; MARTINS, B. C.; ROCHA, F. S.; BOIÇA JUNIOR, A. L.; CARBONEL, S. A. M.; CHIORATO, A. F. 2010b. Behavior of bean genotypes to attack by Bemisia tabaci (Genn.) biotype B (Hemiptera: Aleyrodidae). Arquivo do Instituto Biológico 77 (4): 635-641.

JESUS, F. G.; BOIÇA JUNIOR, A. L.; ALVES, G. C.; ZANUNCIO, J. C. 2014. Behavior, development, and predation of Podisus nigrispinus (Hemiptera: Pentatomidae) on Spodoptera frugiperda (Lepidoptera: Noctuidae) fed transgenic and conventional cotton cultivars. Annals of the Entomological Society of America 107 (3): 601-606.

LARA, F. M. 1991 Princípios de resistência de plantas a insetos. São Paulo, Ícone. 336 p.

MALDONADO, S.H.G.; MARÍN-JARILLO,A.; CASTELLANOS, J. Z.; MEJIA, E. G.; ACOSTA-GALlEGOSC, J. A. 1996. Relationship between physical and chemical characteristics and susceptibility to Zabrotes subfasciatus (Boh.) (Coleoptera: Bruchidae) and Acanthoscelides obtectus (Say) in common bean (Phaseolus vulgaris L.) varieties. Journal of Stored Products Research 32 (1) 53-58. doi:10.1016/0022-474X(95)00037-8.

MORANDO, R.; BALDIN, E. L. L.; CRUZ, P. L.; LOURENÇÃO, A. L.; CHIORATO, A. F. 2015. Antixenosis of bean genotypes to Chrysodeixis includens (Lepidoptera: Noctuidae). Pesquisa Agropecuária Brasileira 50 (6): 450-458. doi:10.1590/S0100204X2015000600003.

PAIVA, L. A. DE; CORRÊA, F.; SILVA, C. L. T.; MOURA, T. L.; DA SILVA, F. C.; ARAÚJO, M. S.; DE JESUS, F. G. 2016. Resistance of corn genotypes to fall armyworm Spodoptera frugiperda (Lepidoptera: Noctuidae). African Journal of Biotechnology 15 (35): 1877-1882.

PEDROSA, M. M.; CUADRADO, C.; BURBANO, C.; MUZQUIZ, M.; CABELLOS, B. OLMEDILLA-ALONSO, B.; ASENSIO-VEGAS, C. 2015. Effects of industrial canning on the proximate composition, bioactive compounds contents and nutritional profile of two Spanish common dry beans (Phaseolus vulgaris L.). Food Chemistry 166 (1): 68-75. doi:10.1016/j. foodchem.2014.05.158.

SEIFI, A.; VISSER, R. G. F.; BAI, Y. 2013. How to effectively deploy plant resistances to pests and pathogens in crop breeding. Euphytica 190 (3): 321-334. doi:10.1007/s10681-012-0823-9. 
SILVA, T. R. F. B.; ALMEIDA, A. C. S.; MOURA, T. L.; SILVA, A. R.; FREITAS, S. S.; JESUS, F. G. 2016. Effect of the flavonoid rutin on the biology of Spodoptera frugiperda (Lepidoptera: Noctuidae). Acta Scientiarum Agronomy 38 (2): 165-170. doi: 10.4025/actasciagron.v38i2.27956.

SMITH, C. M. 2005 Plant resistance to arthropods: molecular and conventional approaches. Berlin, Springer. $423 \mathrm{p}$.

STATSOFT Inc. 2004. Statistica (data analysis software system), version 7. Avaliable in: www.statsoft.com.

WAR, A. R.; PAULRAJ, M. G.; AHMAD, T.; BUHROO, A. A.; HUSSAIN, B.; IGNACIMUTHU, S.; SHARMA. H. C. 2012. Mechanisms of plant defense against insect herbivores. Plant Signal Behavior 7 (10): 1306-1320. doi:10.4161/psb.2166.
Received: 22-Mar-2016 • Accepted: 20-Oct-2017

Suggested citation:

PAIVA, L. A. de; RESENDE, W. de C.; SILVA, C. L. T.; ALMEIDA, A. C. S.; CUNHA, P. C. R.; JESUS, F. G. 2018. Resistance of common bean (Phaseolus vulgaris) cultivars to Spodoptera frugiperda (Lepidoptera: Noctuidae). Revista Colombiana de Entomología 44 (1): 12-18. Enero - Junio 2018. 